\title{
Nařízení o statusu a financování evropských politických stran - nová úprava svobody politického sdružování v Evropské unii
}

\author{
Regulation on the Statute and Funding of European \\ Political Parties and European Political Foundations \\ and the Future of the Freedom of Political Association in \\ the European Union
}

Jan Grinc*

\begin{abstract}
Abstrakt
Př̀spèvek analyzuje novou unijni prámi úpravu evropskéch politických stran a jeji genezi. Piovodnè navrhovaný velmi restriktivni režim s pochybnými prostredky práuni ochrany byl prïbližèn evropským standardiom svobody politického sdružováni ažv prüběbu legislativního procesu. Prestože evropsképolitické strany nejsou svou povahou zcela srovnatelné s vnitrostátnimi, z. blediska vývoje evropské integrace nelze jejich potenciál podceňovat. Proto jejich právni úpravu nelze vyjimat z. požadavkì kladených na regulaci politických stran ve státech Rady Evropy. Geneze nařzeni pak vybizí i k úvahám o významu politické odpovédnosti a veréjné kontroly pro ochranu politické svobody.
\end{abstract}

Klíčová slova

Europské politické strany; svoboda sdrư̌ování; politické sdružováni; Evropská unie.

\section{Abstract}

The article analyses the new EU regulation of European Political Parties and its genesis. The initial proposal of a very stringent regime with questionable safeguards of legal protection bas only been approximated to the European standards of freedom of political assembly in the course of the legislative procedure. Although the European Political Parties are not fully comparable to national political parties in their nature, their potential importance in the process of European integration cannot be underestimated. Therefore their legal regulation cannot be exempt from requirements that have to be met by the regulation of political parties in the Council of Europe member states. The genesis of the new EU regulation also begs a question on the importance of political accountability and public control for the protection of political freedom.

Keywords

European Political Parties; Freedom of Association; Political Association; European Union.

\footnotetext{
* Mgr. Jan Grinc, Ph.D., Katedra ústavního práva, Právnická fakulta Univerzity Karlovy v Praze / Department of Constitutional Law, Faculty of Law, Charles University, Prague, Czech Republic/ E-mail: grinc@prf.cuni.cz
} 


\section{1 Úvod}

Téma ochrany základních práv v Evropské unii nabývá stále většího významu. Odborná literatura věnuje značnou pozornost především judikatuře Soudního dvora EU k otázkám základních práv, Listině základních práv EU („Listina“) a také vztahu mezi vnitrostátními, mezinárodněprávními a unijními mechanismy a institucemi ochrany základních práv. Postupně se ale rozvíjí i unijní úprava jednotlivých základních práv předpisy sekundárního práva. Jedním z předmětů této úpravy jsou i politické strany na evropské úrovni, které podle čl. 10 odst. 4 Smlouvy o Evropské unii („SEU“) a čl. 12 odst. 2 Listiny prispívají k utváření evropského politického vědomí a k vyjadřování politické vůle občanů Unie.

Politické strany na evropské úrovni - evropské politické strany - nejsou klasickými politickými stranami. Odlišují se zejména ve dvou ohledech. Za prvé nesdružují primárně fyzické osoby, nýbrž vnitrostátní politické strany. Za druhé nejsou způsobilé podávat kandidátní listiny k volbám do Evropského parlamentu. To mohou činit vnitrostátní politické strany popř. jiné subjekty a sdružení, kterým to umožňuje vnitrostátní právo. Spíše jde tedy o jakási zájmová sdružení politických stran. Nejstarší evropské politické strany se formovaly souběžně s evropskou integrací, avšak předmětem právní úpravy se staly až mnohem později.

Podle čl. 224 Smlouvy o fungování Evropské unie („SFEU“) Evropský parlament a Rada stanoví řádným legislativním postupem formou nařízení pravidla, kterými se řídí politické strany na evropské úrovni a zejména jejich financování. Donedávna byla tato právní úprava obsažena v nařízení Evropského parlamentu a Rady č. 2004/2003 o statutu a financování politických stran na evropské úrovni („staré nařízeni“"). V září 2012 Komise předložila návrh nařízení o statutu a financování evropských politických stran a evropských politických nadací („návrh Komise“). ${ }^{2}$ Ten byl dne 22. října 2014 s významnými změnami přijat jako nařízení Evropského parlamentu a Rady č. 1141/2014 o statusu a financování evropských politických stran a evropských politických nadací („nové nařízení). Nařízení přináší některé zásadní novinky, především zakotvení právní subjektivity evropských politických stran podle unijního práva, úpravu jejich registrace a kontrolní a sankční mechanismy až po možnost vyškrtnutí strany z rejstř́iku. Dochází též ke změnám v úpravě financování evropských politických stran a regulovány jsou i evropské politické nadace, jimž se však tento př́spěvek dále věnovat nebude. ${ }^{3}$

1 K vývoji evropských politických stran např. ZBÍRAL, Robert. Financování evropských politických stran: žádný povyk a presto něco? In: ŠIMÍČEK, Vojtěch. Financování politickébo šivota. Brno: MUNI Press, 2015, zejm. s. 96-100.

2 Dokument COM(2012) 499.

3 K evropským politickým nadacím např. GAGATEK, Wojciech a Steven VAN HECKE. The development of European political foundations and their role in strengthening Europarties. Acta Politica, 2014, roč. 49 , s. $86-104$. 
Problémem evropských politických stran je, že při volební kampani do Evropského parlamentu stojí ve stínu vnitrostátních politických stran a v období mezi volbami zase ve stínu politických skupin vytvářených v Evropském parlamentu. ${ }^{4}$ Přesto je patrná snaha evropské politické strany zviditelnit nebo i právně posílit, která ostatně byla i důvodem předložení návrhu Komise. Vedle něj je třeba zmínit iniciativu z volební kampaně v roce 2014, kdy hlavní evropské politické strany vyhlásily souboj svých lídrů (tzv. Spitzenkandidaten) o post předsedy Komise. Prostrednictvím Evropského parlamentu pak vyvíjely tlak na Evropskou radu, aby na tento post automaticky navrhla kandidáta té evropské politické strany, která volby vyhraje. Mělo tak dojít k větší politizaci Komise. Nejnověji pak Evropský parlament předložil návrh novely Aktu o volbě členů Evropského parlamentu ve všeobecných a př́mých volbách. ${ }^{5}$ Ve svém návrhu ${ }^{6}$ mimo jiné usiluje $\mathrm{o}$ to, aby na volebních lístcích a $\mathrm{v}$ dalších volebních materiálech byla viditelně uváděna př́slušnost kandidujícího subjektu k evropské politické straně a případně i odkaz na program této strany. Evropský parlament se vrací i k myšlence celoevropského volebního obvodu pro volbu části europoslanců z kandidátních listin sestavovaných evropskými politickými stranami. ${ }^{7}$ Regulace evropských politických stran tedy přes určitá specifika těchto organizací bezprostředně souvisí s procesy formujícími evropské politické vědomí a s otázkou politického pluralismu v Evropském parlamentu a ve volbách do něj.

Evropská unie se zřetelně hlásí k základním právům vyplývajícím ze společných hodnot členských států a zvláště k těm, která jsou zaručena Úmluvou o ochraně lidských práv a základních svobod (čl. 2, čl. 6 odst. 3 SEU). Podle čl. 52 odst. 3 Listiny jsou smysl a rozsah práv zaručených Listinou, která odpovídají právům zaručeným Úmluvou, stejné jako ty, které jim prrikládá Úmluva, nebo širší. V souladu s tím Vysvětlení k Listině konstatují, že záruka svobody sdružování dle čl. 12 Listiny odpovídá záruce obsažené v čl. 11 Úmluvy. Bylo by tedy logické, aby se EU při tvorbě předpisů, které tato základní práva provádějí, řídila standardy společnými svým členským státům a Radě Evropy a v jejich

4 Srov. HANLEY, David. Outside their comfort zone? National parties, European Parliament groups and transnational parties. In: MAGONE, José M. Routledge Handbook of European Politics. London/New York: Routledge, 2014, zejm. s. 669-670 a 679-680. V současném volebním období tvoří jednu politickou skupinu v Evropském parlamentu jedna nebo dvě evropské politické strany a dále nezávislí poslanci nebo poslanci vnitrostátních politických stran, které nejsou členkami žádné evropské politické strany.

5 Př́loha rozhodnutí Rady 76/787/ESUO, EHS, Euratom (Úř. věst. L 278, 8. 10. 1976, s. 1) ve znění pozdějších předpisů.

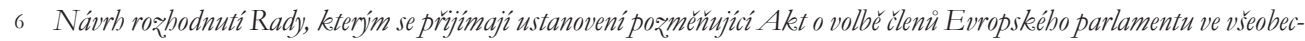
ných a prímých volbách, tvoríci prǐlobu usneseni Evropskébo parlamentu ze dne 11. listopadu 2015 o reformè volebníbo práva Evropské unie. 2015/2035 (INL) [online]. 11. 11. 2015 [cit. 1.3. 2016]. Dostupné z: http://www.europarl. europa.eu/sides/getDoc.do?pubRef=-//EP//TEXT+TA+P8-TA-2015-0395+0+DOC+XML+V0//CS

7 Jde o novelizační bod 2 (vložení čl. 2a) citovaného návrhu. V minulém volebním období Evropský parlament navrhoval, aby se $\mathrm{v}$ tomto obvodě rozdělovalo 25 mandátů. Viz Drubá zpráva Výboru pro ústavní záležitosti Evropskébo parlamentu o návrbu zmèny aktu ze dne 20. zárĭ 1976 o volbè clenu Evropského parlamentu ve všeobecných a primých volbách. 2009/2134(INI) [online]. 2. 2. 2012 [cit. 1.3. 2016]. Dostupné z: http://www.europarl. europa.eu/sides/getDoc.do?pubRef=-//EP//TEXT+REPORT+A7-2012-0027+0+DOC+XML+V0//CS 
rámci volila vhodné modely regulace uzpůsobené své specifické povaze supranacionální organizace. Tyto minimální standardy lze blíže dovozovat nejen z judikatury Evropského soudu pro lidská práva, ${ }^{8}$ ale i ze srovnání právních úprav ve státech Rady Evropy. ${ }^{9}$ Návrh Komise však vyvolal řadu právních otázek a z důvodů, které budou dále uvedeny, jej bylo možno považovat za neslučitelný s uvedenými standardy. Př́jatý text nového nařízení řadu problémů odstranil nebo alespoň zmírnil. Některé však přetrvaly.

V následujícím textu bude vždy shrnuta a analyzována právní úprava ve starém nařízení, v návrhu Komise a v novém nařízení. Zaměříme se přitom na úpravu registračních, kontrolních a sankčních postupů. Jen stručně se dotkneme otázky financování, která je však neméně významná.

\section{Vymezení evropské politické strany, podmínky, proces a důsledky její registrace}

Staré nař́zení definovalo „politickou stranu na evropské úrovni“ ve svém čl. 2 a čl. 3 odst. 1 jako politickou stranu nebo svazek (strukturované společenství) politických stran splňující následující podmínky: (1.) má právní subjektivitu v členském státě, v němž se nachází její sídlo; (2a.) je alespoň v jedné čtvrtině členských států zastoupena členy Evropského parlamentu nebo v celostátních či regionálních parlamentech, nebo (2b.) obdržela alespoň v jedné čtvrtině členských států alespoň $3 \%$ hlasů odevzdaných v každém z nich při posledních volbách do Evropského parlamentu; (3.) dodržuje zejména ve svém programu a při svých činnostech hodnoty, na kterých je založena EU, tj. hodnotu svobody, demokracie, dodržování lidských práv a základních svobod a právního státu, (4.) účastnila se voleb do Evropského parlamentu nebo vyjádřila úmysl se jich zúčastnit. Splnění uvedených čtyř podmínek, tedy naplnění znaků politické strany na evropské úrovni, bylo předpokladem pro to, aby se takový subjekt mohl ucházet o finanční prostředky z unijního rozpočtu.

Nové nařízení zavedlo kratší pojem „evropská politická strana“. Definuje ji v čl. 2 jako politické spojenectví (strukturovanou spolupráci) mezi politickými stranami a/nebo občany, které sleduje politické cíle a je v souladu s dále uvedenými pravidly zaregist-

8 Viz např. KOSAŘ, David. Judikatura ESLP v oblasti rozpouštění politických stran. Jurisprudence, Praha: Wolters Kluwer, 2009, roč. XVIII, č. 7, s. 31-45 nebo komentář téhož autora k čl. 11 Úmluvy In: KMEC, Jiř́; KOSAŘ, David; KRATOCHVÍL Jan a Michal BOBEK. Evropská úmluva o lidskéch právech. Komentár. 1. vydání. Praha: C. H. Beck, 2012, s. 1099-1177.

9 Viz zejm. obecné dokumenty Evropské komise pro demokracii prostřednictvím práva (tzv. Benátská komise): EUROPEAN COMMISSION FOR DEMOCRACY THROUGH LAW (VENICE COMMISSION): Report on the Establishment, Organisation and Activities of Political Parties. Study no. 247/2003. Strasbourg: Council of Europe, 2004; Guidelines on Political Party Regulation by OSCE/ODIHR and Venice Commission. Study no. 595/2010. Strasbourg: Council of Europe, 2010; Guidelines on Prohibition and Dissolution of Political Parties and Analogous Measures. Strasbourg, Council of Europe, 2000; Guidelines on Legislation on Political Parties: Some Specific Issues. Study no. 247/2003. Strasbourg: Council of Europe, 2004, vše dostupné z: http:// www.venice.coe.int/webforms/documents/?topic=15\&year=all [cit. 2. 1. 2016]. 
rováno na evropské úrovni. Stojí za pozornost, že oproti minulé úpravě se zdůrazňuje možnost přímého individuálního členství fyzických osob v evropských politických stranách. ${ }^{10}$ Nové nařízení přebírá i čtyři výše uvedené požadavky obsažené ve starém nařízení, a to jako podmínky registrace politického spojenectví jako evropské politické strany (čl. 3 odst. 1 nového nařízenî). Doplňuje k nim podmínku pátou, jíž je neziskový účel, a modifikuje podmínku třetí: výčet hodnot se rozšiřuje o úctu k lidské důstojnosti, rovnosti a právům př́slušníků menšin. Návrh Komise dále stanovil, že evropská politická strana musí tyto hodnoty dodržovat i prostřednictvím činnosti svých členů (tedy zejména vnitrostátních politických stran a jejich představitelů). Tato úprava však do konečného znění nepronikla.

Čl. 4 nového nařízení upravuje minimální obsah stanov evropské politické strany, včetně požadavků na vnitrostranickou demokracii. Tyto stanovy je třeba spolu s dokumenty dokládajícími splnění podmínek registrace přiložit k žádosti o registraci evropské politické strany (čl. 8 odst. 2 nového nařízení).

Zajímavým vývojem prošla podoba registrační procedury. Podle čl. 6 návrhu Komise měl o registraci politického spojenectví rozhodovat Evropský parlament. Ten měl do tří měsíců od obdržení žádosti o registraci přijmout rozhodnutí, které by se zveřejnilo v Úředním věstníku EU bud' společně se stanovami strany, pokud by bylo žádosti vyhověno, anebo - „když žádost nebyla schválena“ - s důvody pro její zamítnutí.

Čl. 8 nového nařízení nakonec svěřuje posouzení žádosti Úřadu pro evropské politické strany a evropské politické nadace („Ú̌rad“). Jasně je stanoveno, že jsou-li podmínky pro registraci splněny, Úřad přijme rozhodnutí o registraci žadatele a zveřejní je v Úředním věstníku do jednoho měsíce od obdržení žádosti. Je-li žádost neúplná, vyzve Úřad k jejímu doplnění. K prokázání, že strana dodržuje hodnoty EU, postačuje prohlášení žadatele. Úřad tedy nebude moci požadovat další důkazy tohoto stavu, což by bývalo mohlo vést k oddalování rozhodnutí o registraci. Je-li registrace zamítnuta, zveřejní se v Úředním věstníku podrobné odůvodnění tohoto rozhodnutí.

Při srovnání s právními úpravami v členských státech Rady Evropy zjišt'ujeme, že v řadě z nich se registrace politických subjektů nevyžaduje, není povinná, nebo zde subjekty s politickými cíli podléhají pouze obecné úpravě spolků. Pokud je registrace vyžadována, postačuje k ní zpravidla jen splnění formálních podmínek. Pouze menší část států klade při registraci politických stran požadavky na hodnotový obsah jejich politického programu, ve smyslu zákazu hlásit se k některé ideologii nebo prosazovat násilí jako prostředek k dosažení politických cílů. Není překvapivé, že jde taǩ̌ka výlučně o státy se zkušeností

10 Téměř všechny evropské politické strany jsou v současnosti založeny především na členství vnitrostátních politických stran. Individuální členství má spíše symbolický a čestný význam. Týká se zejména poslanců Evropského parlamentu a jiných významných funkcionářů. 
S autoritativním nebo totalitním režimem. ${ }^{11}$ Návrh Komise volil právě tento v podstatě nejpřísnější model, nebot’ jako podmínku registrace vyžadoval, aby strana nejen ve svém programu, ale i ve své činnosti a prostřednictvím činnosti svých členů dodržovala hodnoty, na kterých je založena Evropská unie. Již při registraci by se tak bývalo mohlo posuzovat dosavadní politické jednání představitelů strany na vnitrostátní úrovni.

Návrh Komise rovněž jasně nestanovil, zda má mít registrující orgán při rozhodování nějaké uvážení. V členských státech Rady Evropy zpravidla po splnění zákonem stanovených podmínek vzniká straně na registraci právní nárok, nebo strana vzniká již okamžikem, kdy př́slušnému orgánu doloží, že splnila zákonem stanovené podmínky. ${ }^{12}$ Jazykový výklad čl. 6 odst. 5 návrhu Komise nasvědčoval tomu, že v př́padě evropských politických stran má jít naopak o povolovací režim, v němž má rozhodující orgán uvážení, zda žádosti vyhoví, i když tato splňuje požadované náležitosti. Aniž by bylo třeba zkoumat, zda šlo pouze o neobratnou formulaci, nebo o úmysl předkladatele, je žrejmé, že takové znění právního předpisu vyvolává přinejmenším právní nejistotu, které by se měl normotvůrce př̀i úpravě takto zásadních otázek vyvarovat. ${ }^{13}$ Komise pouze $\mathrm{v}$ nezávazném dokumentu $\mathrm{k}$ diskusi uváděla, že odepření registrace by mělo připadat v úvahu pouze při zjevném porušování evropských hodnot. ${ }^{14}$

Tento problém byl $\mathrm{v}$ konečné podobě nařízení odstraněn a registrační procedura se i v důsledku dalších změn nyní jeví v zásadě standardně a automatizovaně a ne jako nástroj k detailnímu zkoumání hodnotového zaměření strany, která teprve vzniká a nezačala se ještě projevovat. ${ }^{15}$ Je samozřejmě třeba zdůraznit, že registrace není podmínkou existence nebo činnosti politického spojenectví účastnícího se politické soutěže na evropské úrovni. Nic nebrání existenci volných sdružení s vnitrostátní právní subjektivitou. Evropské politické strany ostatně dosud působily většinou jako nezisková sdružení podle belgického práva. Registrace za evropskou politickou stranu však má některé významné důsledky.

11 VENICE COMMISSION: Guidelines on Political Party Regulation by OSCE/ODIHR and Venice Commission. Study no. 595/2010. Strasbourg: Council of Europe, 2010, s. 19; táž, Report on the Establishment, Organisation and Activities of Political Parties. Study no. 247/2003. Strasbourg: Council of Europe, 2004, s. 5-9.

12 VENICE COMMISSION: Report on the Establishment, Organisation and Activities of Political Parties. Study no. 247/2003. Strasbourg: Council of Europe, 2004, s. 5-9.

13 Srov. i požadavek Evropského soudu pro lidská práva na jednoznačnost podmínek registrace spolků v rozsudcích Koretskyy proti Ukrajině (3. 4. 2008, č. 40269/02) a Scientologická cirkevv v Moskeve (Church of Scientology Moscow) proti Rusku (5. 4. 2007, č. 18147/02).

14 Commission services non-paper. Proposal for a Regulation on the statute and funding of European political parties and European political foundations. Respect of EU values. 5. 11. 2012, s. 3: „Evaluation of applications would seek to assess, on the basis of available evidence, whether manifest breaches of European values exist."

15 I z judikatury Evropského soudu pro lidská práva vyplývá, že neumožnění vzniku strany je výraznějším zásahem do základních práv než její následné rozpuštění, a proto vyžaduje zvláštní ospravedlnění. Viz rozsudky Tsonev proti Bulharsku (13. 4. 2006, č. 45963/99, odst. 60) a Linkov proti Ceské republice (7. 12. 2006, č. 10504/03, odst. 45). 


\section{Důsledky registrace a pravidla financování}

Registrací především vzniká politické straně evropská právní subjektivita (čl. 15 nového nařízenî). Tu staré nařízení neupravovalo. Evropská právní subjektivita má stranám zaručit plné právní uznání a způsobilost k právním úkonům ve všech členských státech (čl. 13 nového nařízenî). Právní režim evropských politických stran podle nového nařízení však není komplexní. Podpůrně se uplatní i právní rád členského státu, v němž má strana své sídlo (čl. 14 nového nařízenî). K zániku evropské právní subjektivity evropské politické strany dochází podle čl. 16 nového nařízení výmazem z rejstríku. Straně se pak obnovuje její původní subjektivita podle prúislušného vnitrostátního právního řádu. Výmaz z rejstříku je zejména sankcí ( $k$ tomu viz dále), ale provede se samozřejmě i na žádost evropské politické strany, pokud např. hodlá ukončit svou činnost.

Registrace se dále stává podmínkou prístupu k financování z unijního rozpočtu. Podmínky prístupu evropských politických stran $\mathrm{k}$ veřejnému financování $\mathrm{z}$ rozpočtu Unie se oproti starému nařízení zpř́ísňují. Doposud postačovalo prokázat splnění těch požadavků, které jsou nyní podmínkami registrace. Nově je možnost čerpání veřejných prostředků zachována pouze těm evropským politickým stranám, které, vedle toho, že jsou registrovány, jsou též zastoupeny alespoň jedním členem v Evropském parlamentu (čl. 17 odst. 1 nového nařízenî).

Ze starého nařízení zůstává zachován klíč $\mathrm{k}$ rozdělení prostředků mezi jednotlivé evropské politické strany: $15 \%$ bude rozděleno rovným dílem a $85 \%$ poměrně podle počtu členů Evropského parlamentu (čl. 19 nového nařízenî). Př́spěvky z rozpočtu Unie mohou tvořit až $85 \%$ ročních způsobilých nákladů evropské politické strany (čl. 17 odst. 4). Naopak př́spěvky vybírané evropskou politickou stranou od jejích členů nesmí přesáhnout $40 \%$ jejích ročních způsobilých nákladů (čl. 20 odst. 7). Omezení veřejného financování pouze na evropské politické strany zastoupené v Evropském parlamentu je problematické, nebot' paušálně znevýhodňuje mimoparlamentní (tj. i nové) strany. ${ }^{16}$ Omezení príspěvků od členských stran mělo dle R. Zbírala patrně vyrovnat vnitřní mocenské poměry evropských politických stran vychýlené ve prospěch velkých členských stran z bohatých států, ale důsledkem je zase závislost evropských politických stran na veřejném financování popř. (zatím spíše teoreticky) na darech. ${ }^{17}$

Za pozornost stojí i úprava nakládání evropských politických stran s jejich finančními prostředky v čl. 21 a 22 nového nařízení. Jejím cílem je, aby tyto prostř̌edky nesloužily k ovlivňování vnitrostátní politiky v členských státech. Mohou být použity k financování kampaní vedených evropskými politickými stranami v souvislosti s volbami do Evrop-

16 Srov. též VENICE COMMISSION. Guidelines on Political Party Regulation by OSCE/ODIHR and Venice Commission. Study no. 595/2010. Strasbourg: Council of Europe, 2010, s. 39.

17 ZBÍRAL, Robert. Financování evropských politických stran: žádný povyk a přesto něco? In: ŠIMÍČEK, Vojtěch. Financování politickébo života. Brno: MUNI Press, 2015, s. 95-118. 
ského parlamentu, avšak stranám se zakazuje přímo či nepřímo financovat kampaně k celostátním, regionálním či místním volbám či referendům a financovat vnitrostátní politické strany či kandidáty. V návrhu Komise na tato ustanovení nenavazovala žádná sankce. V přijatém nařízení to bylo napraveno.

Kromě výše uvedeného nové nařízení podrobně upravuje finanční kontrolu a pravidla pro přjijimání darů evropskými politickými stranami. Administrace příspěvků z rozpočtu EU a finanční kontroly je z větší části svěřena tzv. schvalující osobě Evropského parlamentu a řídí se podrobnějšími předpisy, zejm. tzv. finančním nařízením. ${ }^{18} \mathrm{Na}$ dodržování podstatné části povinností spojených s financováním má ale současně dohlížet i Úřad (čl. 24 odst. 2 nového nařízenî).

Otázky financování by si zasloužily samostatný rozbor, pro který zde však není prostor. Již zmiňovaný text R. Zbírala uvádí, že podoba této právní úpravy odpovídá jevu kartelizace politických stran, tj. vyhovuje především velkým etablovaným politickým stranám. Zbíral zmiňuje rưzné kritiky této právní úpravy a ukazuje, jaké výkladové problémy vyvolává zákaz financování vnitrostátních politických stran a jejich kampaní. Pozitivně se staví ke změně formy financování z grantů na př́spěvky. ${ }^{19}$ Podrobnou (a dosud relevantnî) analýzu úpravy financování podle starého nařízení publikoval H. H. von Arnim. ${ }^{20}$ Kritizoval mimo jiné absenci horní hranice celkového objemu finančních prostředků rozdělovaných mezi politické strany, o které tak (v rámci sestavování rozpočtu Evropského parlamentu) rozhodují samy politické strany, možnost téměř úplného financování evropských politických stran z veřejných zdrojů, omezení př́stupu k $85 \%$ celkových prostředků pouze na strany zastoupené v Evropském parlamentu, jakož i rozdělování těchto prostředků podle počtu mandátů v Evropském parlamentu, které znevýhodňuje strany úspěšné spíše ve velkých členských státech. Navrhoval spravedlivější model, $\mathrm{v}$ němž by se prostředky rozdělovaly podle poměru hlasů získaných členy jednotlivých evropských politických stran v Evropské unii jako celku.

\section{4 Úřad pro evropské politické strany}

Návrh Komise předpokládal, že veškerá rozhodnutí o registraci, výmazu z rejstř́ku nebo o jiných sankcích bude přijímat Evropský parlament. Právě role Evropského parlamentu byla asi nejvýznamnějším a na první pohled patrným problémem návrhu.

První zcela zásadní otázkou kompetenční povahy bylo, zda může být Evropskému parlamentu aktem sekundárního práva vůbec svěřena pravomoc vést správní řízení a přijímat

18 Nařízení Evropského parlamentu a Rady (EU, Euratom) č. 966/2012, kterým se stanoví finanční pravidla o souhrnném rozpočtu Unie a o zrušení nařízení Rady (ES, Euratom) č. 1605/2002.

19 ZBÍRAL, Robert. Financování evropských politických stran: žádný povyk a přesto něco? In: ŠIMÍČEK, Vojtěch. Financování politickébo života. Brno: MUNI Press, 2015, s. 95-118.

20 VON ARNIM, Hans Herbert. Die neue EU-Parteifinanzierung. Neue Juristische Wochenschriftt. München: C. H. Beck, 2005, č. 5, s. 247-253. 
správní akty upravující práva a povinnosti třetích osob. Něco takového neodpovídá ani obecnému vymezení funkcí Evropského parlamentu v čl. 14 odst. 1 SEU, ani povaze tohoto orgánu jako parlamentu. Proto se domnívám, že to bez výslovné opory v primárním právu není možné. ${ }^{21}$

I kdybychom problém pravomoci pominuli, zbývá mnoho dalších. V členských státech Rady Evropy rozhoduje o otázkách registrace politických stran v zásadě bud’ soud (někde i ústavní soud), ministerstvo (vnitra či spravedlnosti) nebo zvláštní volební orgán, nikoli však parlament. ${ }^{22} \mathrm{~V}$ případě ukládání sankcí, zejména při rozpouštění politických stran, pak musí být konečné rozhodnutí svěřeno soudu. ${ }^{23}$ Důvody jsou naprosto zřejmé. Politická strana je pro její nečleny v parlamentu konkurentem v politické soutěži. Již tím je zpochybněna nestrannost rozhodujícího orgánu. Jakmile se navíc rozhodování o kontrole a sankcích stane předmětem hlasování politicky složeného orgánu, může se stát také předmětem politických dohod. ${ }^{24}$

Návrh Komise tyto problémy vůbec nereflektoval, a to ani v souvislosti s možným hlasováním členů evropské politické strany v jejich vlastní věci, kde by vznikal zjevný střet zájmů. V navrhovaném systému totiž nehrozila jen diskriminace politických konkurentů, ale i nevynucování pravidel vůči politickým partnerům.

Již zmíněný non-paper Komise uvažoval, že o registraci pravděpodobně nebude rozhodovat plénum Evropského parlamentu, nýbrž jeho předsednictvo na základě doporučení generálního tajemníka, jak tomu v praxi doposud bylo s žádostmi o finanční prostřed-

21 Možný protiargument neexistencí nebo oslabením klasických ústavních modelů zákonodárného orgánu v institucionálním systému EU neobstojí, nebot’ tento zvláštní rys organizačního uspořádání EU neplyne sám ze sebe, nýbrž je založen právě ustanoveními primárního práva. Ta však Evropskému parlamentu žádné správní funkce tohoto typu nepřiznávají.

22 VENICE COMMISSION. Report on the Establishment, Organisation and Activities of Political Parties. Study no. 247/2003. Strasbourg: Council of Europe, 2004, s. 8-9. Určitou výjimku představuje Irsko, kde rozhoduje zvláštní úředník jedné z komor parlamentu (Clerk of Dáil Éireann), proti jehož rozhodnutí se lze odvolat k orgánu tvořenému soudcem irského Nejvyššího soudu a předsedy obou komor parlamentu. Viz VENICE COMMISSION. Guidelines on Probibition and Dissolution of Political Parties and Analogous Measures. Strasbourg, Council of Europe, 2000, s. 20.

23 VENICE COMMISSSION. Guidelines on Probibition and Dissolution of Political Parties and Analogous Measures. Strasbourg, Council of Europe, 2000, s. 5, 9-10, 20; táž: Guidelines on Political Party Regulation by OSCE/ ODIHR and Venice Commission. Study no. 595/2010. Strasbourg: Council of Europe, 2010., s. 45.

24 Jeden z recenzentů tyto teze zpochybnil s poukazem na kontrolu financování českých politických stran Poslaneckou sněmovnou podle zákona č. 424/1991 Sb., o sdružování v politických stranách a v politických hnutích. Srovnání těchto právních úprav ale ukazuje jasné rozdíly. Sněmovna především nemůže rozhodovat o právech a povinnostech politické strany. Právní důsledky má pouze nepředložení finanční zprávy Sněmovně (důvod k rozpuštění strany soudem podle $\int 13$ odst. 6 zákona) nebo předložení takové zprávy, která neobsahuje všechny formální náležitosti stanovené v \18 zákona (Ministerstvo vnitra v takovém prrípadě podle $\int 20 \mathrm{a}$ zákona pozastaví straně výplatu př́íspěvku na činnost). Není zde po mém soudu reálný prostor pro zneužití. Podezření na porušení zákona plynoucí z obsahu finančních zpráv musí Sněmovna řešit podnětem k finančnímu úřadu ( $\int 19 \mathrm{a}$ odst. 3 zákona). 
ky podle starého nařízení. ${ }^{25}$ I kdyby se akcentovala role generálního tajemníka jako vedoucího administrativního aparátu Evropského parlamentu, je sporné, jakou funkční a rozhodovací nezávislost by tato osoba jmenovaná a odvolávaná právě předsednictvem měla. Jinou otázkou je, zda by vưbec bylo možné k delegaci na předsednictvo přistoupit, pokud nařízení stanoví, že rozhoduje Evropský parlament. Nebylo by takto možno přenést rozhodování o registraci např. na předsedu Evropského parlamentu jako jakéhosi vedoucího tohoto „správního orgánu“? Komisí předpokládané pokračování dosavadní praxe každopádně nedávalo žádnou právně vynutitelnou záruku. Naopak bylo možno argumentovat, že i dosavadní praxe byla v rozporu s právní úpravou.

Popsaná právní konstrukce proto nebyla do konečného znění převzata. Čl. 6 nového nařízení zřizuje a podrobně upravuje již zmiňovaný Úřad pro evropské politické strany a evropské politické nadace, jehož účelem je registrace, kontrola a ukládání sankcí evropským politickým stranám a nadacím. Úřad má mít samostatnou právní subjektivitu a má být nezávislý. Je zdůrazněno, že ve svých rozhodnutích Úřad „plně zohledňuje základní právo - svobodu sdružování a potřebu zajistit pluralismus politických stran v Evropěc،. Veškerá rozhodnutí Úřadu přijímá jeho ředitel. Ten je jmenován na pětileté období bez možnosti opakování dohodou Evropského parlamentu, Rady a Komise na základě návrhů, které po otevřeném výběrovém řízení předloží komise složená z generálních tajemníků těchto tří orgánů. Upravena je neslučitelnost výkonu funkce ředitele Úřadu zejména se zastáváním jakéhokoli voleného mandátu nebo i prací pro evropskou politickou stranu. Ředitel může být odvolán, pokud již nesplňuje podmínky výkonu funkce, a to dohodou alespoň dvou ze tři orgánů, které ho jmenují, opět na základě zprávy výběrové komise. Opakovaně je zdůrazněno, že ředitel vykonává své povinnosti nezávisle a nesmí vyžadovat ani přijímat žádné pokyny. Ředitel ovšem může být výše uvedenými orgány EU pověřen „i jinými úkoly“, pokud to neohrožuje jeho „plnou nezávislost“. Úřad se má fyzicky nacházet v Evropském parlamentu, což mu podle znění čl. 6 odst. 4 nového nařízení „umožňuje využívat potřebné kancelářské prostory a zařízení administrativní podpory“. Všichni ostatní zaměstnanci mají být Úřadu přiděleni jedním nebo více orgány Unie s tím, že při pracovní činnosti vykonávané pro Úrad se tito zaměstnanci řídí výhradně pokyny ředitele Úřadu.

Čl. 224 SFEU, který je právním základem nařízení, samozřejmě zrŕizení takového úřadu vůbec nepředpokládá. Patrně tedy měl být právním základem nařízení i čl. 352 SFEU (doložka flexibility), což by znamenalo nutnost přijmout nařízení jednomyslným rozhodnutím Rady namísto kvalifikované většiny platné pro čl. 224. Sporná je i možnost svěřit Úřadu rozhodovací pravomoci, nebot' primární právo nic takového nepředpokládá. Je tedy otáz-

25 Commission services non-paper. Proposal for a Regulation on the statute and funding of European political parties and European political foundations. Respect of EU values. 5. 11. 2012, s. 3: „The initial registration procedure under Article 6 could involve a formal plenary decision (similar to the decision-making procedure under Article 7(2)) but it is more likely that Parliament would maintain the current approach, consisting of decisions by the Bureau, based on recommendations from the Secretary-General of EP.“ 
kou, zda je nové nařízení v těchto ohledech vůbec v souladu s primárním právem. Soudní dvůr nicméně bez výraznějších ohledů na zásadu svěření pravomocí aproboval zrrizování podobných institucí s rozhodovacími pravomocemi předpisy sekundárního práva. ${ }^{26}$

\section{Ověřování podmínek registrace}

Z čl. 5 starého nařízení byla do čl. 7 návrhu Komise převzata procedura tzv. ověřování. Ta dosud umožňovala vyloučit z financování z rozpočtu Unie politickou stranu, která v daném roce přestala splňovat stanovené podmínky - pojmové znaky evropské politické strany. Podle návrhu Komise měl Evropský parlament obdobně při posuzování ročních žádostí evropských politických stran o př́íspěvky pravidelně přezkoumávat, zda žadatel splňuje veškeré podmínky pro registraci. Kdykoli by o to navíc požádala čtvrtina členů Evropského parlamentu zastupující alespoň tři politické skupiny, měl Evropský parlament většinou hlasů svých členů rozhodnout, zda evropská politická strana nadále při své činnosti dodržuje hodnoty, na kterých je založena Evropská unie (čl. 7 odst. 2 návrhu Komise). Před prrijetím rozhodnutí měl Evropský parlament vyslechnout zástupce strany a požádat o stanovisko tříčlenný výbor složený z nezávislých osobností, do něhož po jednom jeho členu jmenují Evropský parlament, Rada a Komise. Také kterákoli fyzická nebo právnická osoba měla mít možnost kdykoli podat odůvodněnou žádost o ověření, zda evropská politická strana dodržuje podmínky registrace (čl. 7 odst. 3 návrhu Komise).

Jak je vidět, v této části návrhu se Komise pokusila překrýt zjevný střet zájmů na straně Evropského parlamentu konstrukcí tříčlenného výboru, jehož nezávislost by však spočívala jen v tom, že dva z jeho členů by nebyli jmenováni př́mo Evropským parlamentem. Jeho stanovisko by navíc nebylo pro Evropský parlament nijak závazné, resp. návrh Komise nic takového nestanovil.

Podle čl. 6 odst. 2 a čl. 10 nového nařízení bude pravidelné ověřování, zda registrované evropské politické strany stále splňují podmínky pro registraci (včetně požadavků na obsah stanov), provádět Úřad. Shledá-li, že strana některou podmínku nesplňuje, uvědomí ji o tom. Zvláštní postup je pak stanoven pro ověrování, zda strana dodržuje hodnoty, na nichž je založena EU. To musí vždy navrhnout Evropský parlament, Rada nebo Komise (Úřad jim k tomu může dát podnět), popř. členský stát, v němž má strana sídlo. Tuto otázku pak nezkoumá nezávislý Úřad, nýbrž „Výbor nezávislých významných osobnosti““ („Výbor“) upravený v čl. 11 nového nařízení, který k ní do dvou měsíců vydá veřejné stanovisko. Výbor je šestičlenný, po dvou členech do něj vysílají Evropský parlament, Rada a Komise. Pro členy výboru platí obdobná pravidla inkompatibility jako pro ředitele Úřadu, také nesmějí vyžadovat ani přijímat žádné pokyny. Výbor se obmě-

26 Podrobně SVOBODOVÁ, Magdalena. Evropské agentury v recentní judikatuře Soudního dvora EU. Právník, 2015, roč. 154, č. 5, s. 378-393. 
ňuje po každých volbách do Evropského parlamentu (vždy do šesti měsíců od prvního zasedánî). Výbor má mít k dispozici i sekretariát, který poskytuje Evropský parlament. Pro účely zpracování stanoviska si může od evropské politické strany nebo i od jejích členů vyžádat jakýkoli dokument nebo požádat o vyslechnutí jejich zástupců. Úřad pak „s ohledem na stanovisko“ Výboru rozhodne o zrušení registrace evropské politické strany a o jejím výmazu z rejstř́ku, jestliže zjevně a závažně porušuje hodnoty, na nichž je založena EU. Toto rozhodnutí ovšem vstoupí v platnost pouze tehdy, pokud proti němu Evropský parlament a Rada nevznesou ve lhůtě tří měsíců odůvodněné námitky. Podle čl. 10 odst. 3 nového nařízení se ověřování nemá zahajovat v období dvou měsíců před volbami do Evropského parlamentu. Nic ale nebrání tomu, aby bylo v uvedené době již zahájené řízení dokončeno výmazem strany z rejstříku.

Řešení zvolené v novém nařízení je jasným zlepšením oproti návrhu Komise, byt' je procesně dosti složité. Nadále však lze pochybovat o skutečném oddělení rozhodujících institucí od Evropského parlamentu. Nezávislost Úřadu a jeho ředitele je sice všemožně deklarována, avšak s výjimkou způsobu jmenování a pevného funkčního období není nijak zaručena - Úřad má sídlit přímo v Evropském parlamentu, jeho zaměstnanci budou patrně z velké části přiděleni rovněž Evropským parlamentem. Podobně to platí pro Výbor, který se má navíc obměňovat vždy po volbách do Evropského parlamentu.

\section{Ukládání sankcí}

Staré nařízení upravovalo jedinou sankci - vyloučení strany z financování z rozpočtu Unie. Návrh Komise k tomu doplňoval peněžitou pokutu a výmaz z rejstř́íku.

Pokutu měl podle čl. 22 odst. 2 a 3 návrhu Komise ukládat Evropský parlament. Podle nového nařízení je tato pravomoc svěřena Úřadu. Dle čl. 27 odst. 2 nového nařízení se uloží v následujících skupinách případů: (1.) porušení obecných informačních povinností: evropská politická strana neoznámí Úřadu změnu stanov nebo změnu na seznamu členských stran, záměrně neuvede některé informace, poskytne nesprávné či zavádějící informace nebo nepředloží dokumenty požadované Úřadem; (2.) porušení povinností v souvislosti s pravidly financování: evropská politická strana nenahlásí prrijetí darů a jejich dárce, přijme dary, které není oprávněna přijmout, poruší některý ze zákazů vztahujících se na její výdaje, nepředloží pravidelné účetní dokumenty nebo jiné dokumenty vyžadované Úřadem, Evropským úřadem pro boj proti podvodům (OLAF) nebo schvalující osobou, jsou zjištěny podstatné nepřenosnosti v její roční účetní závěrce nebo je pravomocně odsouzena za protiprávní činnost poškozující finanční zájmy Unie. Tato úprava se od původního návrhu Komise príliš neliší.

Výše pokuty měla být podle návrhu Komise pro jednotlivé skutkové podstaty určena na základě stupnice stanovené Evropským parlamentem s horním limitem 10 \% ročního rozpočtu evropské politické strany. Čl. 27 nového nařízení však nakonec tyto sazby 
stanoví pevně sám. Obecně bude pokuta činit $5 \%$ z ročního rozpočtu strany. Tato částka se může snížit na třetinu, pokud evropská politická strana dobrovolně oznámí dané protiprávní jednání předtím, než Úřad oficiálně zahájí vyšetřování. Při vícečetném či opakovaném porušení se sazba naopak zvyšuje. Právní úprava se tak pohybuje ode zdi ke zdi. Zatímco návrh Komise dával Evropskému parlamentu volnou ruku v bližším určení sazeb pokut, přijaté nařízení nepřipouští prakticky žádné uvážení.

Druhou sankcí je již zmiňovaný výmaz evropské politické strany z rejstř́ḱku. Podle čl. 22 odst. 1 a 4 návrhu Komise mohl Evropský parlament o výmazu rozhodnout v následujících př́ípadech: (1.) po zjištění, že evropská politická strana nedodržela hodnoty, na kterých je Unie založena, v rámci procedury ověřování, (2.) strana byla pravomocně odsouzena za protiprávní činnost poškozující finanční zájmy Unie, (3.) strana nedodržuje minimální pravidla vnitrostranické demokracie, nebo (4.) strana jakýmkoli jiným způsobem přestala plnit podmínky registrace a nezavedla $\mathrm{v}$ přiměřené lhưtě nápravná opatření požadovaná Evropským parlamentem. Čl. 27 odst. 1 nového nař́zení z těchto možností zachoval první dvě. Čtvrtou upravil tak, že stranu lze vymazat z rejstř́ku, jestliže nemá sídlo v některém členském státě nebo sleduje ziskový účel. $\mathrm{K}$ tomu byl doplněn případ, kdy evropská politická strana podle rozhodnutí orgánů členského státu závažným způsobem neplní požadavky vnitrostátního práva, které se na ni subsidiárně vztahují podle místa jejího sídla. Nyní tak není zcela zřejmé, co se má stát, pokud evropská politická strana ztratí minimální parlamentní zastoupení na evropské, národní a regionální úrovni, resp. volební podporu, které jsou podmínkou pro její registraci. ${ }^{27}$ Aby v takovém prrípadě automaticky docházelo nejen ke ztrátě veřejného financování, ale i k výmazu z rejstř́ku, jak to bylo upraveno v čl. 11 odst. 1 písm. c) návrhu Komise, bych považoval za velmi problematické, nebot' by to omezovalo možnosti strany dobýt v politickém boji ztracené pozice zpět - oslabovalo by to např́klad její atraktivitu pro nové členské strany. Byla by tedy narušena politická soutěž. ${ }^{28}$ Proto zastávám názor, že nařízení je třeba vykládat $\mathrm{v}$ tom smyslu, že výmaz strany z rejstř́k

Specifickou sankcí je vyloučení evropské politické strany z veřejného financování. Tato sankce, ukládaná zejména za vážná pochybení v účetnictví, je zčásti upravena již zmiňovaným finančním nařízením, na které nařízení o evropských politických stranách odkazuje. Čl. 22 odst. 5 návrhu Komise spojoval s uložením pokuty (z jakéhokoli důvodu)

27 Viz odkazy na čl. 3 odst. 1 písm. b) v 17 odst. 3, čl. 24 odst. 2 a 4, čl. 29 odst. 3 a čl. 30 odst. 2 (ztráta minimální reprezentativnosti znamená nesplnění podmínek pro přístup $\mathrm{k}$ finančním prostředkům EU) a naopak absenci jasného odkazu v čl. 27 nového nařízení.

28 Zde lze vést určitou paralelu s rozsudkem Evropského soudu pro lidská práva Republikánská strana Ruska (Republican Party of Russia) proti Rusku (12. 4. 2011, č. 12976/07, odst. 114 a 115), kde soud mj. odmítl argument, že status politické strany by měl být vyhrazen pouze pro dostatečně reprezentativní sdružení, a kritizoval úpravu ukládající stranám povinnost každoročně dokládat počet členů pod hrozbou rozpuštění. Odůvodnění tohoto rozhodnutí samožrejmě nelze široce zobecňovat a bez dalšího přenášet na specifickou situaci evropských politických stran. 
automatickou ztrátu nároku na prríspěvek z rozpočtu EU v daném kalendářním roce, což by vedlo k pozastavení tohoto financování a povinnosti vrátit neoprávněně poskytnuté nebo dosud nevyužité prostředky. Podle čl. 27 odst. 3 nového nařízení může schvalující osoba evropskou politickou stranu vyloučit z financování až na pět let také při odsouzení za protiprávní čin poškozující finanční zájmy Unie, př̀i nepřesnostech v účetní závěrce nebo při úmyslném porušení informačních povinností.

I zde je mezi návrhem Komise a schváleným textem zřetelný pozitivní posun. Návrh Komise byl v některých ohledech tak odtržený od principů právního státu, že vyvolával otázky, které snad ani Evropský soud pro lidská práva dosud nemusel posuzovat - zmiňme jen navrhované ukládání sankcí Evropským parlamentem, které naprosto pomíjí, že v tomto tělese zasedají př́mí političtí konkurenti sankcionovaného subjektu.

\section{Procesní záruky, prováděcí předpisy a opravné prostředky}

Jestliže Komise navrhovala svěřit rozhodování o evropských politických stranách Evropskému parlamentu, mohla se pokusit alespoň zčásti zmírnit rizika s tím spojená přesnou procesní úpravou rozhodování. To se však nestalo. Podle čl. 23 návrhu Komise měl Evropský parlament před přijetím konečného rozhodnutí o sankcích umožnit dotčené evropské politické straně, aby předložila své připomínky, a bylo-li by to relevantní a vhodné, aby přijala opatření potřebná pro nápravu situace v přiměřené lhưtě. Mohl též poskytnout slyšení jiným fyzickým či právnickým osobám, považoval-li by to za nezbytné. Čl. 28 návrhu Komise obecně zmocňoval Evropský parlament k úpravě pravidel a postupů pro provádění nařízení. K tomu připočtěme již zmiňované zmocnění Evropského parlamentu ke stanovení sazeb pokut za porušení nařízení. Čl. 26 návrhu pak zvláště uváděl, že Evropský parlament stanoví správní postupy pro odvolání proti rozhodnutím týkajícím se registrace stanov, financování či sankcí. Odvolací správní řízení však nemělo mít odkladný účinek, ledaže by podle názoru Evropského parlamentu okolnosti vyžadovaly pozastavení uplatňování jím přijatého rozhodnutí. Rozhodnutí príjatá na základě nařízení měla být podle návrhu Komise přezkoumatelná v řízení před Soudním dvorem Evropské unie. Prakticky by se mohlo jednat zejména o žaloby dotčené politické strany na neplatnost jí adresovaného rozhodnutí podle čl. 263 SFEU.

Navržená úprava vyvolávala dvě základní otázky. První spočívala v tom, zda je možné aktem sekundárního práva delegovat na Evropský parlament tvorbu právních předpisů. Dle mého názoru je odpověd’ záporná. Smlouvy umožňují zmocnit k vydání právních aktů v přenesené pravomoci nebo k provedení legislativních aktů pouze Komisi a v určitých př́padech Radu (čl. 290, 291 SFEU), nikdy však Evropský parlament. Mimo tento rámec mají být obecně závazná pravidla obsažena přímo v aktech sekundárního práva, 
tj. v nařízení samém. Obecně je jistě přípustné, aby Evropský parlament podrobněji upravoval určité interní záležitosti vlastními vnitřními předpisy. ${ }^{29}$ Taková opatření ale nejsou ani právními akty, a proto jimi nelze upravovat tak závažné otázky, v takovém rozsahu a s tak širokým uvážením, jak Komise navrhovala. Regulace politických stran nadto na rozdíl od regulace parlamentních klubů není vnitřní věcí Evropského parlamentu, což mimo jiné vylučuje její úpravu jednacím řádem Evropského parlamentu (čl. 232 SFEU). Zde by se jednalo dokonce o právní úpravu dotýkající se základního práva na politické sdružování. Soudní dvůr EU v souvislosti s prováděcími předpisy zaujal názor, že jimi nemohou být upraveny otázky vyžadující politická rozhodnutí (politické volby řešenî) nebo významně se dotýkající základních práv třetích osob. ${ }^{30}$ Do této kategorie lze jistě řadit i základní procesní pravidla při uplatňování základních práv nebo ukládání sankcí. O těchto otázkách musí stanoveným postupem rozhodovat unijní normotvưrce, tedy Evropský parlament a Rada. Domnívám se proto, že tak rozsáhlé zmocnění, jaké bylo obsaženo v čl. 26 a 28 návrhu Komise, by bylo v rozporu s právem EU, i kdyby bylo určeno Komisi.

Druhá otázka se vztahovala ke koncepci opravných prostředků. Z návrhu Komise nebylo zřejmé, jak má Evropský parlament rozhodovat o odvolání proti svému vlastnímu rozhodnutí. Mělo jít o autoremeduru, nebo o přezkum jiným tělesem v rámci Evropského parlamentu? Problematické bylo i uvážení Evropského parlamentu o přiznání odkladného účinku, a to i v př́padě odvolání proti rozhodnutí o vyškrtnutí evropské politické strany z rejstř́ku nebo uložení jiné sankce. Konečně nebyla stanovena ani žádná lhůta pro rozhodnutí o opravném prostředku. Prozatímně pozastavit provádění napadeného rozhodnutí mohl v dalším kroku i Soudní dvưr, ale to by již pro stranu, která byla mezitím vyškrtnuta $\mathrm{z}$ rejstříku a ztratila finanční prostředky z rozpočtu Unie, nemělo velký význam. I kdyby bylo rozhodnutí později zrušeno a registrace obnovena, mohlo v mezidobí dojít k těžko napravitelnému zásahu. Ve světle výše uvedeného se nabízela úvaha, zda odvolací řízení nevypustit a neumožnit po rozhodnutí Evropského parlamentu rovnou jeho soudní přezkum. Vršení procesních prostředků totiž může ve svém důsledku efektivní uplatnění práva i ztížit. Jestliže by např́klad Evropský parlament při rozhodování o žádosti o registraci evropské politické strany v plné míře využil tříměsíční lhůtu podle návrhu Komise, následně by se konalo časově neomezené odvolací rízení, a teprve poté by došlo na řízení před soudem, byl by vznik evropské politické strany dlouho blokován.

Nové nařízení tyto problémy vyřešilo. Přijímání prováděcích předpisů Evropským parlamentem bylo z konečného znění vypuštěno. Komisi je sice v souladu s čl. 290 SFEU svěreno přijímání aktů v přenesené pravomoci, avšak jedná se spíše o konkretizaci po-

29 V současnosti existuje např́klad rozhodnutí Předsednictva Evropského parlamentu z 29. března 2004, které stanoví technické detaily k postupu při financování činnosti evropských politických stran.

30 Rozsudek Soudního dvora EU ve věci C-355/10 Parlament v. Rada, zejm. odst. 76-77. 
vinností stanovených jasně již v samotném nařízení (čl. 7 odst. 2 a čl. 8 odst. 3 nového nařízenî). Rovněž odpadlo odvolací řízení, takže rozhodnutí, popř. i nečinnost Úřadu či schvalující osoby lze napadnout u Soudního dvora (čl. 6 odst. 11 a čl. 35 nového nařízenî). Procesní úprava sice zůstala kusá, avšak předpokládá jednoměsíční lhůtu k nápravě před přjietím jakéhokoli rozhodnutí o sankcích a povinnost vyslechnout zástupce dotčené evropské politické strany (čl. 29 a 34 nového nařízení).

\section{Možné protiargumenty}

K výše uvedeným kritickým poznámkám lze vznést přinejmenším tři souhrnné protiargumenty. Dvěma z nich je společná teze, že nařízení ve skutečnosti neupravuje podmínky výkonu základního práva a není tedy možné jeho obsah poměřovat vnitrostátními úpravami politického sdružování.

Především lze namítat, že evropské politické strany nejsou kvalitativně srovnatelné s klasickými vnitrostátními politickými stranami, zejména vzhledem k charakteru jejich členství a k funkcím, které reálně plní. Nejedná se v pravém smyslu o demokraticky budované organizace občanů, nýbrž spíše o kluby vnitrostátních politických stran. Dále lze tvrdit, že návrhem nařízení není regulována samotná činnost politických subjektů, tedy jakési jádro práva na politické sdružování, nýbrž pouze jejich právní režim a financování z veřejných prostředků. Registrace evropské politické strany není podmínkou její politické činnosti, volebních kandidatur nebo přiznání právní subjektivity (postačí-li jí právní subjektivita podle některého vnitrostátního právního řádu).$^{31}$

Domnívám se, že tyto argumenty nemohou převážit. Je-li dlouhodobou ambicí politických sil v Evropské unii prohlubovat integraci, stimulovat podmínky vedoucí k formování evropského politického vědomí a evropské politické identity občanů a posilovat prvky parlamentarismu, včetně rozšiřování pravomocí Evropského parlamentu, což vše umocňuje význam evropských politických stran, měly by být na druhou stranu přísně dodržovány požadavky, které jsou na právní regulaci politické soutěže kladeny v demokratických právních státech, nebot' vycházejí z určitých historických zkušeností a jsou podloženy přesvědčivými argumenty. Budou-li tyto požadavky ignorovány, nebo budou-li plněny jen selektivně, může se právo EU propracovat ke stavu, který již bude z hlediska standardů základních práv neúnosný.

Evropské politické strany, i když se odlišují od vnitrostátních politických stran, v konečném důsledku také slouží potřebám občanů EU. Není důvod činit rozdíl mezi evropskými a vnitrostátními politickými stranami, pokud jde o férové a spravedlivé podmínky

31 Takto argumentuje již citovaný Commission services non-paper. Proposal for a Regulation on the statute and funding of European political parties and European political foundations. Respect of EU values. 5. 11. 2012, s. 5. Komise zde dále uvádí, že navrhovaná úprava je „v zásadě podobná“ právní úpravě v členských státech a dokonce se dovolává toho, že navrhovaná role Evropského parlamentu nebyla jím samým při debatách o současné právní úpravě zpochybněna (!). 
přístupu k financování z veřejných zdrojů, podmínky zásahu do jejich právní subjektivity a právní záruky při ukládání peněžitých sankcí. Všechny tyto otázky mají ústavněprávní i mezinárodně-lidskoprávní rozměr. $\mathrm{V}$ případě zřízení v úvodu zmiňovaného celoevropského volebního obvodu pro volby do Evropského parlamentu by se navíc registrace evropské politické strany zřejmě stala podmínkou její kandidatury v tomto obvodě, a tedy i podmínkou jejího plnohodnotného prrístupu k volbám. Zde je třeba vzít v potaz, že ochrana politických stran na evropské úrovni vyplývající z čl. 10 odst. 4 SEU a čl. 12 odst. 2 Listiny, nejsou-li tato ustanovení chápána jen jako nenormativní či programová, ${ }^{32}$ nemůže být zužována jen na subjekty, které jsou za evropské politické strany označeny aktem sekundárního práva nebo které jsou zastoupeny v Evropském parlamentu, ale spíše by se měla vztahovat na jakákoli uskupení účastnící se voleb do Evropského parlamentu. ${ }^{33}$ Dopady regulace a její soulad se zárukami základních práv je tedy třeba posuzovat v širším rámci.

Třetí možný protiargument se zakládá na tom, že návrh Komise vycházel ze stávající právní úpravy, s jejímž praktickým fungováním nebyly problémy. ${ }^{34}$

Ani tento argument nepovažuji za přesvědčivý. Podoba dosavadní právní úpravy nebo praxe, ani skutečnost, že nebyly způsobilými subjekty napadeny u Soudního dvora, ${ }^{35}$ není rozhodná pro posouzení jejího souladu s primárním právem, zejména s přihlédnutím k Lisabonskou smlouvou výslovně zakotvené vazbě Listiny na Úmluvu a judikaturu Evropského soudu pro lidská práva. Pokud jde o argument, že dosavadní praxe je uspokojivá, ${ }^{36}$ domnívám se, že ten by mohl hrát roli v př́padě stabilního demokratického systému založeného na dlouhodobém striktním dodržování takových zvyklostí. Regulace evropských politických stran podle starého nařízení však fungovala pouze několik let, v nichž došlo k zásadnímu posunu jejího právního i politického kontextu kompetenčním posilováním Evropského parlamentu.

Určitá rizika naznačil i průběh legislativního procesu v př́ípadě starého nařízení. V Evropském parlamentu probíhala dělící linie mezi velkými a malými stranami, popř. mezi silami podporujícími současnou podobu evropské integrace a ostatními. Velké politické

32 Tak ve vztahu k čl. 10 odst. 4 SEU Jindřiška Syllová In: SYLLOVÁ, Jindřiška; PÍTROVÁ, Lenka; PALDUSOVÁ Helena a kol. Lisabonská smlouva. Komentár. Praha: C. H. Beck, 2010, s. 66.

33 Srov. PÜNDER, Herrman. Kommunikationsgrundrechte. In: EHLERS, Dirk (ed.). Europäische Grundrechte und Grundfreibeiten. Berlin: De Gruyter, 2009, s. 560.

34 Commission services non-paper. Proposal for a Regulation on the statute and funding of European political parties and European political foundations. Respect of EU values. 5. 11. 2012, s. 3-5.

35 Všechny žaloby podané $\mathrm{k}$ Soudnímu dvoru v souvislosti se starým nařízením byly odmítnuty jako nepř́ipustné. Viz usnesení Soudu prvního stupně ve věcech T-13/04 Bonde, T-17/04 Front National a T-40/04 Bonino a usnesení Soudního dvora ve věci C-338/05 Front national.

36 K tomu kriticky VON ARNIM, Hans Herbert. Die neue EU-Parteifinanzierung. Neue Juristische Wochenschriftt. München: C. H. Beck, 2005, č. 5, s. 247-253. Viz též informaci o zamítnutí žádosti o financování politické strany Libertas: EU funding for Libertas on hold after confusion over signatories. EU Observer [online]. 4. 2. 2009 [cit. 1. 3. 2016]. Dostupné z: http://euobserver.com/news/27530 
strany původně požadovaly jako podmínku poskytnutí příspěvků z rozpočtu EU i dlouhodobost fungování žádajícího politického spojenectví a zastoupení jeho členů alespoň $\mathrm{v}$ jedné třetině členských států namísto jedné čtvrtiny. Deklarovaným cílem přitom bylo vyloučit z financování krajně pravicová uskupení. ${ }^{37}$ Tyto návrhy mohly ve svém důsledku menším a novým evropským politickým stranám - bez ohledu na jejich hodnotové zaměření - značně ztížit nebo zcela uzavřít již tak složitý přístup k financování. Byly však následně korigovány členskými státy v Radě. ${ }^{38}$

\section{Závěr}

Jak bylo možno očekávat, návrh Komise doznal v průběhu projednávání významných změn, které jej přiblížily standardům regulace politického sdružování v demokratických právních státech. Mưže se proto jevit jako zbytečné, že se tento text podrobně zabýval i původním návrhem. Domnívám se ale, že je to naopak velmi důležité. Podoba návrhu předloženého Komisí, která z velké části vycházela z požadavků Evropského parlamentu, ${ }^{39}$ totiž dokládá problematický přístup Komise k ochraně základních práv. Přitom právě vysoká úroveň jejich ochrany by měla být jedním z prostředků, jimiž může Unie kompenzovat slabší demokratickou legitimitu svých institucí ve srovnání s ústavními orgány členských států. Návrh Komise však byl zjevně motivován snahou vyhovět Evropskému parlamentu (tedy v zásadě hlavním regulovaným subjektům) bez reflexe základních hodnot, ke kterým se Evropská unie hlásí. To je vzhledem k obecně velmi slabé veřejné kontrole evropské politiky a k potenciálně rostoucímu významu evropských politických stran znepokojivé. Jako patrně nezamýšlená, nicméně velmi funkční pojistka zapůsobilo, že o právní úpravě evropských politických stran nerozhoduje pouze Komise a Evropský parlament, nýbrž i Rada. Z dostupných dokumentů z průběhu legislativního procesu je patrné, že právě Rada zabránila prosazení nejkontroverznějších prvků původního návrhu. Analýza pohnutek účastníků legislativního procesu nebyla předmětem této práce. Troufám si však říci, že roli sehrály zkušenosti členských států s právní úpravou politických práv včetně vnější kontroly v rámci mechanismů Rady Evropy, která Evropské unii chybí.

37 Viz VON ARNIM, Hans Herbert. Die neue EU-Parteifinanzierung. Neue Juristische Wochenschrift. München: C. H. Beck, 2005, č. 5, s. 251, který poznamenává, že pokud takové politické spojenectví porušuje hodnoty, na nichž je Unie založena, pak může být vyloučeno z financování již na základě této skutečnosti, a pokud je neporušuje, pak není možné je cíleně znevýhodňovat jinými prostředky.

38 GAGATEK, Wojciech. Political Financing Regulation at the EU Level: The Conflict of National Traditions and Interests. Working Paper Series on the Legal Regulation of Political Parties, No. 14, Leiden: Leiden University, 2011 [online], zejm. s. 14-18, 20, 25-27. [cit. 1.3. 2016] Dostupné z: http://www.partylaw.leidenuniv.nl

39 Viz důvodovou zprávu k návrhu Komise COM(2012) 499, s. 3-6. Východiskem bylo zejména usnesení Evropského parlamentu ze dne 6. 4. 2011 o uplatňování nařízení (ES) č. 2004/2003 o statutu a financování politických stran na evropské úrovni, 2010/2201(INI). 
Historie vzniku nového nařízení o evropských politických stranách dle mého názoru ilustruje obecnější problém, na který upozornil rakouský právník M. Potacs. ${ }^{40}$ Ten v kontextu řešení finanční a hospodářské krize upozorňoval na nerespektování primárního práva při přijímání některých protikrizových opatření orgány Unie a členskými státy. Podle něj se ukazuje, že vůdčím a v konečném důsledku vždy rozhodujícím principem interpretace evropského práva je effet utile. Primát účelu ale zároveň vede k rozmělnění hodnoty právního řádu, jenž přestává být závazným rámcem, ve kterém se pohybuje politické rozhodování (a který lze stanovenými postupy měnit), a stává se pouhou podle potřeby tvarovatelnou hmotou sloužící $\mathrm{k}$ formálnímu odůvodnění legality právě prosazovaných opatření. Tyto rysy bylo možno pozorovat i v návrhu Komise, který se odvolával na potřebu posílit a povzbudit evropské politické strany jako rozhodující instituce při formulování hlasu občanů na evropské úrovni a na záruku sdružovacího práva, avšak svým obsahem ignoroval normativní požadavky s tím spojené. ${ }^{41}$

Německý právník H. H. von Arnim, který je známý svou kritikou zneužívání veřejné moci politickými stranami k jejich vlastnímu obohacování, označil v roce 2005 staré nařízení podle mého názoru přehnaně za kulminaci demokratického deficitu evropského systému, zejména pokud jde o jeho vzdálenost občanům a politickou nerovnost. Varoval před kartelizací systému evropských politických stran a omezováním politické soutěže. ${ }^{42}$ Těmto tendencím, které jsou do značné míry přirozené, by mohla bránit kvalitní právní úprava postavení a financování evropských politických stran vycházející z osvědčených modelů. Naopak právní úprava, která by takový proces spíše podporovala a vzhledem $\mathrm{k}$ rigiditě práva EU a intenzivnímu zájmu regulovaných subjektů disponujících v rámci Evropského parlamentu jak výlučnou legislativní iniciativou tak i právem veta by byla velmi obtížně změnitelná, by se mohla do budoucna stát problémem pro rozvoj a férovou soutěž evropských politických stran. Z tohoto pohledu je dobře, že nové nařízení obsahuje ve srovnání s návrhem Komise řadu potřebných právních záruk, ačkoli lze mít určité pochybnosti o zárukách nezávislosti Úřadu a Výboru (pomineme-li otázku legality zř́izení Úřadu).

Nařrizení bude účinné od 1. ledna 2017. Úřad má být zřízen do 1. září 2016. Teprve praxe ukáže, jak bude nový systém fungovat. Je možné, že právě vzhledem k průběhu legislativního procesu budou všechny dotčené orgány úzkostlivě dbát o korektní výklad a aplikaci nových pravidel. Popsaná anabáze by ale i tak měla být pro odbornou veřejnost jistým varováním a pobídkou k podrobnějšímu sledování způsobu, jakým je bohatý unijní katalog základních práv reálně naplňován v předpisech sekundárního práva EU.

40 POTACS, Michael. Vom Wert des Rechtes in Europäischen Union. Journal für Rechtspolitik, 2012, roč. 20, č. 1, Springer, Wien, s. 23-30.

41 Viz důvodovou zprávu a preambuli návrhu Komise COM(2012) 499.

42 VON ARNIM, Hans Herbert. Die neue EU-Parteifinanzierung. Neue Juristische Wochenschriftt. München: C. H. Beck, 2005, č. 5, s. 253. 